\title{
Whitewashing Narratives: Israeli Media and the Framing of the Kidnapped Yemenite Babies Affair
}

\author{
Shoshana Madmoni-Gerber, Suffolk University, Boston, MA, USA
}

\begin{abstract}
This essay offers a review of ongoing media analysis of the kidnapped Yemenite Babies Affair in light of recent changes in public awareness since the emergence of social media and the more recent formal governmental recognition. It argues that the government's efforts to silence this affair over decades would not have been possible without the media's full cooperation. Moreover, the public denial of this affair contributes to the ongoing intra-Jewish rift and racism in Israeli society today. Questions regarding the reconciliation and remembrance of this affair in the public sphere will strongly influence the identity formation of Yemenite and Mizrahi children of future generations.
\end{abstract}

"We used to leave in the hospital healthy babies; the next day I would ask them 'where are the babies?' and they said they are gone. They died. What do you mean died? They were healthy. Nothing was wrong with them. Today when they say that they died, it's not true. They were sent for adoption, mostly to the U.S."1 (Nurse Ruja Kuchinski, 1996)

\section{Introduction}

In the winter of 1951, Naomi Gavra, who arrived in Israel from Yemen, gave birth to her son Zion. One evening, when she was nursing her son in the Baby House, where all babies were housed, strangers pulled the baby from her arms, never to be seen again. Neomi gave the following testimony to the investigative program, $U v d a$ : "It was eight in the evening; I was nursing my son, and there were two women and a man who spoke Yiddish. They removed the children. I told a Yemenite caregiver who was with me to ask them where the children were being taken. They said that they were going to the hospital and would bring the babies back in two to three weeks. They left with fourteen babies; I saw them with my own eyes. My first thought was to take my baby and run. But suddenly the two women returned and demanded my baby. When I refused, one of them pulled my hands to the side, and the other ripped the baby from my arms. I ran after their car screaming and crying...I don't think they were Jewish... You need a heart of stone to kidnap a baby like that from his mother's hands..." (Uvda February 13, 1996).

Gavra's story was one of several heartbreaking testimonies featured in the investigative program $U v d a$ in 1996. Other parents such Miriyam Ovadia also testified that her baby daughter,

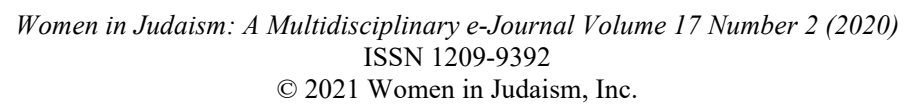

All material in the journal is subject to copyright; copyright is held by the journal except where otherwise indicated. There is to be no reproduction or distribution of contents by any means without prior permission. Contents do not necessarily reflect the views of the editors. 
Zohara, was physically wrenched from her arms by a nurse on her journey from Yemen to Israel. Also, David Shuker, a Yemeni father, shared the details of his decades-long search for his daughter Miriam, who was kidnapped and given up for adoption while he was searching for her throughout the country. ${ }^{2}$

These testimonies illustrate how the Zionist Eurocentric view of the Yemenite and other Mizrahi immigrants (Jews with origins in the Arab and Muslim world) as inferior and unfit parents served as ideological justification behind the power of the state to separate children from their parents (Hertzog 1999, 2019, Lavie 2014). Moreover, it represents the agony felt by hundreds of families grieving the loss of their children and their complete dependence on state authorities for information. And while most of these parents have since passed away, their descendants report a lasting feeling of trauma and pain (Hziza 2019).

Despite the 1,053 testimonies given to three different state commissions, and over 2,000 cases documented by a more recent study (Shifris 2019), this affair is still contested in the public sphere and officially not fully recognized by the Israeli government. Only recently, in February 2021, the government released a statement recognizing "the pain of the families," and announcing an offer of financial compensation. The language used in the resolution, however, was far from offering an admission of guilt or an official acknowledgement of state responsibility. Families and activists expressed their strong objection to what they viewed as an attempt, on the eve of the election, to gloss over their demand for state transparency and responsibility. Rafi Shubeli, a veteran activist with the advocacy group Forum Achai, told the Washington Post (February 22, 2021), that this decision was unilateral and imposed on families. "Our struggle will continue," he said. "This affair isn't going away."

This essay offers a review of my ongoing media analysis of this affair in light of recent changes in public awareness since the emergence of social media and the more recent formal governmental recognition. I argue that the government's efforts to silence this affair over decades would not have been possible without the media's full cooperation. Moreover, I claim that the public denial of this affair contributes to the ongoing intra-Jewish rift and racism in Israeli society today. Questions regarding the reconciliation and remembrance of this affair in the public sphere will strongly influence the identity formation of Yemenite and Mizrahi children of future

Women in Judaism: A Multidisciplinary e-Journal Volume 17 Number 2 (2020) ISSN 1209-9392 (C) 2021 Women in Judaism, Inc.

All material in the journal is subject to copyright; copyright is held by the journal except where otherwise indicated. There is to be no reproduction or distribution of contents by any means without prior permission. Contents do not necessarily reflect the views of the editors. 
generations. In the absence of an honest discussion about the past, the same racist attitudes continue to dictate the present and the future. The same racist attitudes which likely led to the terrible acts of kidnapping in the 1950s also motivated the years-long silencing and the rejection of a legitimate cry for answers. Both the government and the media legitimized this sentiment for too long. Are we witnessing the start of a moment of reckoning? It remains to be seen.

I use a cultural studies approach to examine the mainstream media discourse of this affair, focusing on questions about Western domination, national identity, otherness, memory, and the silencing of dissenting voices. I employ Stuart Hall's $(1990,1992,1996)$ notion of representation, locating contested narrative through textual analysis of this discourse ${ }^{3}$ and interviews with key media professionals and social activists. ${ }^{4}$ I argue that the connection between ideology and power ultimately motivated and dictated the news coverage of this affair and still dominate the official attempt to offer what the government terms "recognition."

\section{What Is the Kidnapped Babies Affair?}

During the mass immigration to Israel from 1948 to the mid 1950s, hundreds, if not thousands, of babies disappeared from immigrant absorption camps and transit camps throughout Israel and from the transit camp, Hashed, in Yemen. According to the testimonies given to the Kedmi Commission (1995-2001) investigating the affair, the absorption policy governing Yemenite Jews required separating children from their parents because the stone structures housing the babies, called Baby Houses, were in better condition than the tents and tin structures that sheltered the parents (Shifris 2019, Zaid 2016). Most babies were taken from the baby houses without parental knowledge or consent. Parents who were present and refused consent reported that camp authorities forcefully took their children from them, even acting with violence. Later testimonies revealed that a typical scenario was the following: A baby was taken to the hospital despite parental assertion that the child was healthy. The baby was then taken to one of several institutions around the country, such as Wizo, an international women's organization with centers in Safed, Jerusalem and Tel Aviv. The parents were told that their baby had died, even as state institutional workers later testified in such cases that these parents were not interested in their children (Shifris 2019, Zaid 2016).

Women in Judaism: A Multidisciplinary e-Journal Volume 17 Number 2 (2020) ISSN 1209-9392

(C) 2021 Women in Judaism, Inc.

All material in the journal is subject to copyright; copyright is held by the journal except where otherwise indicated. There is to be no reproduction or distribution of contents by any means without prior permission. Contents do not necessarily reflect the views of the editors. 
The Yemenite community, while marginalized, has never been silent, and dissent over this affair escalated from a few isolated protests to broad public outcry and appeals to the government. Despite accusations that these babies were kidnapped for adoption in Israel and abroad, the state of Israel failed to properly investigate the matter. The government only responded in the face of considerable public protest, and then in ways assured to create little actual progress.

Up until the middle of the 1960s, most families did not realize the magnitude of what came to be known in Hebrew as the Yemenite Children's Affair. While many knew the state had manipulated them and thus filed complaints with the authorities, it wasn't until families started to receive military draft letters addressed to their "dead" children that people began to organize, leading to the formation of the Public Yemenite committee in 1966. Following the testimonies collected by this committee, the real picture started to emerge, eventually leading to the various state-appointed commissions.

The first official inquiry commission called Bahalul-Minkovski was formed in 1967. The commission examined 342 cases and found that 316 of the babies died, and four were put up for adoption under legally dubious circumstances. The commission did not give any more information concerning these cases and was unable to gather sufficient information to determine the fate of the remaining twenty-two cases it investigated (Zaid 2016).

In 1988, then Prime Minister Yitzhak Shamir appointed a second commission of inquiry, entitled the Shalgi Commission. This commission determined that altogether 613 babies disappeared, and seventy of them were still alive; however, no effort was made to locate them. The publication of these findings was delayed for six years.

In March 1994, before the Shalgi Commission released its findings, a group of Yemenite people and their leader, Rabbi Uzi Meshulam, instituted a protest campaign against the Israeli government's handling of the affair. Rabbi Meshulam, himself of Yemenite origin, with his followers demanded transparency and the formation of an open door public investigative commission. In response, the Israeli police mounted an armed attack on the compound where he and some of his followers resided. For over a month, a large number of police and army forces surrounded Meshulam's house in Yahud and attacked on the morning of May 10, 1994. During the assault, one of Meshulam's followers, a 19-year-old soldier, was killed. Rabbi Meshulam and

Women in Judaism: A Multidisciplinary e-Journal Volume 17 Number 2 (2020) ISSN 1209-9392 
several others from his group were arrested and served prison sentences. ${ }^{5}$

Following Meshulam's civic protest and increasing public pressure, the government in 1995 established the first public investigative commission entitled Cohen-Kedmi. The committee took another six years to release its findings, a delay that puzzled and disappointed the Yemenite community. Families and activists once again found themselves without recourse in the face of deliberate government cover-up. The state, for its part, surely knew that extending the investigation would weaken the case against the state, as the primary witnesses, parents directly affected by the kidnappings, had passed away or considerably increased in age. The Kedmi Commission examined 406 new cases, twenty of them from Hashed transit camp in Yemen. The commission claimed that 391 of them died, fourteen were still missing and one possibly discovered. Of the twenty babies missing from Hashed camp in Yemen, seven died, and thirteen were still missing. ${ }^{6}$

Although officially termed a "public investigative commission," the Kedmi Commission was not what families had anticipated. Important government officials testified behind closed doors, state officials destroyed key records, and the committee rarely used its subpoena power. As legal scholar Boaz Sanjero $(2002,48)$ argued, the commission lacked the central part of any investigation, "an epistemology of suspicion." In fact, Sanjero claimed, suspicion was not present at any stage of the commission's work. Moreover, the Commission forgave "severe actions and omissions" on behalf of camp medical workers and other authorities. For example, essential documents, such as birth records requested by the commission from Hillel Yaffe Hospital were destroyed instead of made available to investigators. Sanjero $(2002,49)$ further noted that "even the suspicion of crimes worse than obstruction of justice were glossed over and forgotten."

\section{Zionist Narrative and Media Discourse}

From the early days of Zionism, Yemeni Jews were excluded and marginalized (Druya 1881, Yosef 1983, Nini 1996, Lavie 2007). Despite the official socialist philosophy, the meeting between Yemenites and Zionists at the turn of the $20^{\text {th }}$ century marked the establishment of racist policies on the ground. This prejudice view identified Yemenites as "simple" and "natural" workers with few needs and transformed them into a deprived and inexpensive labor force. As Zvi Ben Dor (2009) argues, this approach was well orchestrated by the farmers in the colonies, and documented by Zalman Shazar and other influential Zionist leaders. As time went on, public 
expressions about the wider Mizrahi community by politicians and the media reinforced their depiction as primitive and racially inferior. In November 1951, the newspaper Haboker described Jews from Muslim countries as "people with no will for work... [They] lack any understanding and patience to get over the necessary conditions here." A leader of the Jewish Agency, Giyora Yoseftal, characterized Mizrahi immigrants as having "no morals; they are Levantine with dark lives." Specifically, the Moroccans, he stated, "are primitive people and a backward ethnic group." Other leaders referred to Mizrahi immigrants as "inferior human material" and "blacks and primitives," including Prime Minister Ben-Gurion who said, "Yes, there is discrimination, we are compelled to do so."7

The historical review of this Affair demonstrates how the accepted Orientalist knowledge (Said 1978, Shohat 1988) about Mizrahim is intimately linked to the logic that continues to place them as others. It illustrates the power and resilience of what is perceived in Israel as the nation's narrative of unity, a notion that contradicts any attempts to acknowledge wrongdoing in this context. Moreover, the endurance of this discourse for over seven decades is propagated through what Said $(1978,3)$ defines as the state's "supporting institutions." These institutions include the government, academia, the media and the medical establishment especially through "the discourse of hygiene" (Hirsch 2009, 577).

With the exception of some critical voices in Ha'olam Ha'ze in 1967 and $\mathrm{Ha}^{\prime} \mathrm{ir}^{8}$, Ha'aretz, and Channel Two in the mid 1990s, and in the year leading up to the opening of the archives, denial ruled the media coverage. Articles were mostly aligned with government's versions of events instead of challenging them. The discourse was framed as a "mystery" and the children or babies as "lost" or "vanished." As a result, the media produced a narrative that obfuscated rather than investigated the affair. ${ }^{9}$ Ultimately, a wide national call for an open investigation was never generated. Ha'olam Ha'ze (January 11, 1967) was the first media outlet to bring the story to the attention of the public as a criminal phenomenon and frame the story as a narrative of kidnapping. The magazine reported that the kidnapped babies were sent abroad for adoption at a cost of $\$ 5,000$ US per child. This alternative coverage, however, paled by comparison to the overwhelming narrative that supported the government's denial. This line of investigation of the kidnapping of 
Yemenite babies for adoption in the US was also never fully pursued by the government's investigation.

Most importantly, the media's main role was in framing (Entman 2007) this narrative as a "Yemenite problem." The title "The Yemenite Children's Affair," served as a substantial barrier that prevented a more complex understanding of the issue, and prevented the formation of a wider coalition, with other organizations, in the fight for justice. Moreover, it not only maintained a perception that this affair was a Yemenite problem only, but a perception that Yemenite people were the problem, thus never transforming the discourse to questions of state and society's responsibility. As Cornel West argued in Race Matters (1993), part of the barrier in the public discourse about race is the view of black people as "problem people." This framework, West says, is paralyzing. It prevents society from dealing with the more crucial question of "what this way of viewing black people reveals about us as a nation" (2-3).

\section{Practices of Silencing Dissenters}

In looking back, patterns of silencing dissenters were predictable. Media coverage appeared mostly in waves that corresponded with the inquiry commissions; it was mostly reactive, and anecdotal, and newspapers rarely initiating their own investigations beyond reporting on isolated stories (Madmoni-Gerber 2009). Apart from some critical coverage in the $1990 \mathrm{~s},{ }^{10}$ mainstream media assumed a passive role in deliberating and investigating this affair. It was lacking what Sanjero $(2002,48)$ identifies regarding the Kedmi Commission's work, as a crucial component for any investigative work. As Sanjero (2002) argues, suspicion of criminal acts was not considered at any stage of the Commission's work. My analysis of the media discourse points to a similar trend. Ilana Dayan, prominent journalist and host of the show Uvda on Channel Two, was one of few journalists to break this silence. She stated that

There is a gap between the depth of the pain, the magnitude of the Affair, and the media treatment...The ability to prevent the Yemenites from effective form of expression for so long is unbelievable. Especially because we think of ourselves as an open society, but the truth is that different groups in society have no access to power focal points and effective forms of expression (Interview, Summer 2001).

To use Stuart Hall's (1996) framework, the discourse of the Yemenite Babies Affair represents a classic example of what he terms 'the discourse of the West and the Rest,'

Women in Judaism: A Multidisciplinary e-Journal Volume 17 Number 2 (2020) ISSN 1209-9392 (C) 2021 Women in Judaism, Inc.

All material in the journal is subject to copyright; copyright is held by the journal except where otherwise indicated. There is to be no reproduction or distribution of contents by any means without prior permission. Contents do not necessarily reflect the views of the editors. 
emphasizing the inferiority of the East and always, as Edward Said (1978) noted, in relation to European superiority. This includes classifying and dividing the population into simplistic categories, constructing distorted images, and providing models of comparison through difference. The hegemonic system of representation created a media discourse that utilized this formula by maintaining the Zionist authority over the validity of events, especially by actively silencing controversial versions of the story. As Hall $(1990,224)$ noted, "Every regime of representation is a regime of power." Thus, the close link of power/knowledge, a la Foucault, can explain how the media used their power not only to distort information but also to block knowledge perceived as "too explosive." As Yael Tzadok, a journalist with Israeli radio, said, "The separating line that usually exists between the press, the political and juridical establishment, which is essential to democracy, disappeared in this case. The press and the establishment have been welded into one entity, which made a combined, two-headed effort to bury the story" (Interview, summer 2008).

Furthermore, the media denied access to Yemenites families and activists seeking further investigation and demanding answers. Veteran Yemenite activist Rafi Shubeli, who is instrumental in tracking and documenting the affair as well as the media's coverage, said he was personally silenced on several occasions. Ultimately, he said, "There was a discourse in the media about us but without us, and it looked completely natural to them" (Interview, summer 2001). Shubeli further claimed that while the media sensationalized individual stories for rating purposes, it consistently silenced Yemenite activists trying to make claims that were perceived as "too dangerous." At the same time the media magnified state authorities narrating this Affair publicly, thus weakening the Yemenite community's demand for justice. The state's efforts to silence discussion of this perspective could have only been possible with the media's full cooperation over a long period of time.

\section{Public Denial and the Regime of Truth}

While complaints of disappeared/kidnapped children were lodged with the government as early as 1950, the media published, at the time, only few isolated stories. More extensive coverage did not emerge until the mid-1960s, primarily in the form of reporting the actions and demands of the Yemenite Public Committee ${ }^{11}$ and the Bahalul Minkovski commission, but also questioning the very existence of the Affair. Denial dominated the discourse. ${ }^{12}$ The most common theme 
promoted by the media advanced the notion that kidnapping of babies from their parents in the state of Israel was inconceivable and therefore could not have happened. The press considered the notion to be so outrageous that accusers and victims were subject to counterattacks for making such obscene claims. Maariv (October 9, 1966) stated in an unsigned (editorial style) article, "Lost children are not an acceptable phenomenon in this country." The writer questioned the motives of Tuvia Sulami, chair of the Yemenite Public Committee, and outright denied the validity of the kidnapping claim. In fact, the term "kidnapped" always appeared in quotation marks to suggest that claims this ridiculous are probably baseless. "If these actions took place as he [Sulami] says, don't you think the police would have opened some files to investigate these 'kidnappings'?"

"Continuing Psychosis," was another title in Ha'aretz (November 13, 1985) claiming that babies were ill, and their parents deserted them in the hospital. Other articles quoted authority figures supporting this notion and framing the affair as the Yemenite's "wild imagination." The head of the Rambam hospital in Haifa, for instance, stated, "Despite the fact that I didn't work in this hospital at that time, I can guarantee that no child was released from the hospital, not to its legal parents" (Davar February 17, 1967). The hospital records manager verified this notion saying, "It is inconceivable that such a story happened in the hospital without us hearing about it." (Davar February 17, 1967). Another article quoted three anonymous physicians, heads of pediatrics at two hospitals at the time, declaring, "Never, never! was a child released from the hospital without identification." (Tel-Aviv, December 20, 1985). Later nurses' testimonies countered Yemenite accusations by emphasizing over and over again that unwell, misidentified children arrived daily to the absorption camps, and many died, were neglected or even abandoned by their parents. One nurse said that Yemenite babies "died like flies, and we had no time to inform the parents." Another nurse even said that Yemeni parents didn't want their children after they recovered because "one was limping or didn't have his hand...the parents didn't want them." (Mabat Sheni, September 24, $1986^{13}$ )

The Western media exercised their power by operating in what Michel Foucault (1980, 131) defines as the "regime of truth." As Foucault explains, what is accepted as "truth" is the basis for distinguishing between other true and false statements. Foucault argues that the power to produce influential discourse is implicit in the power to make it true. In other words, media 
discourse is one system through which power operates in society (Hall 1992). In Israel, the Zionist meta-narrative is accepted as the regime of truth. ${ }^{14}$ According to this narrative, the Jewish people were victims of anti-Semitism through the ages and were "saved...out of their primitive conditions," and into life in their homeland (Shohat 1988, 3). This self-perception of Jews as victims and the theme of 'rescue' are the cornerstone of the regime of truth in the Israeli state; it is deeply rooted in what constitutes the "common sense" of Israeli life (Ram 2006). While the rationale of Jews as victims can be used to justify state oppression or aggression for defense reasons, it is directly contradicted by the Yemenite Babies narrative. The Jews, in addition to being victims, have victimized others on a racial basis within a decade of the Holocaust. The state narrators, as Ella Shohat (2004) explains, "argue for privileged ownership of historical pain. Memories that endanger the hegemonic discourse are forbidden, become taboo and disappear from the public arena" (6). The subsequent denial of this affair was strongly supported by historians, reporters, and other authority figures charged with selecting, presenting, and archiving information.

While moral outrage on the part of mainstream Ashkenazi society silenced discussion for decades, as demonstrated above, the link between the power of authority figures and the power of the media to give them voice played a significant role as well. In examining this link between knowledge, power, and discourse, it is not my purpose to search for the ultimate true discourse but to examine competing narratives, to locate the power struggle behind them, and point to practical powerful gains. As Hall $(1992,293)$ said, "It is power, rather than the facts about reality which make things true."

Individuals willing to refute Yemenite accusations, such as anonymous nurses and doctors, as in the example above, were presented as authorities despite a lack of corroborating evidence. A proper investigation would have treated them as suspects. This became a major tactic of the media to silence discussion. Quotations often came from individuals such as absorption camp doctors, nurses, and others who might have been implicated in investigations of the Affair. Camp doctors and nurses unequivocally denied wrongdoing. Their statements became the backbone of arguments used to silence challenges to the government position. Foucault (1972) referred to this strategy as "discourse formation." The articles mentioned above served to banish the suspicion that children 
were intentionally separated from their parents, ${ }^{15}$ while emphasizing the good work of clinical staff at the camps. This is the heart of the what Robert Entman (2007) defines as a "framing process;" constructing narratives "with a few elements of perceived reality and highlighting the connection among them to promote a particular interpretation (164)."

As Edward Said (1978) noted, Western authority over a given text or narration of historical events in part through the testimony of academic experts and journalists. Seemingly, these "experts" determined the acceptable limits of controversy within the boundaries of the "truth," which in term rendered their statements "true." Experiences of Yemenite parents were viewed as exaggerated tales that emanated from disorganization and cultural misunderstanding, while experts and authority figures' accounts were accepted as facts.

The Kedmi Commission took a similar approach, clearly preferring state official testimonies to authenticate the state's point of view. Suitable "experts" were chosen if their testimony fit the Kedmi Commission's needs. As Boaz Sanjero (2002) noted, the Kedmi Commissions glossed over, or worse forgave, serious oversights on behalf of camp medical workers and other authorities.

\section{Yemenites as Others}

Since the 1960s, narratives featuring Yemenite families while sometimes blaming the victims, still expressed sympathy for the families of lost children but ignored the magnitude of the Affair. A focus on individual stories usually featured similar scenarios of "disappearance" without demanding public investigation. In retrospect, the many different stories published over the years merged into one story with different names, all the while sidestepping the broader issue. This discourse exemplifies Hall's $(1989,445)$ description of racist discourse. "Racism," he said, "operates by constructing impassable symbolic boundaries between racially constitute categories." The Yemenites were alienated and defined as the "other" by the dominant group, and the discourse about them was constructed through what Hall calls a "binary system of representation." A recent unpublished report ${ }^{16}$ by the Ministry of Health, in the news site Walla, featured testimonies by doctors and nurses clearly stating that Yemeni children should be removed from their biological families for "their own good." A doctor from Hillel Yaffe hospital in Hedera said: "They are having too many children and it's inflicting misery upon them they should be sterilized." Another 
nurse described the new immigrants from Yemen as "neglected and smelly...there are not suitable to be parents" (March 30, 2021).

This discourse was further supported and established through visual representation. As Oren Soffer (1998) noted, pictures of "typical Yemenites," often unrelated to the issue covered, accompanied the articles, in addition to using direct quotes that stressed their "broken Hebrew." This coverage sharpened the divisions between "us" and "them." Possible coalitions with human rights groups, woman's groups, or other social justice organizations on the left were never formed; this affair remained solely a Yemenite problem, partially due to the European domination of the Israeli left. Activist Shubeli said, when he tried to request the help of a human rights organizations, he received a very "polite and cold" response. ${ }^{17}$

Otherness of Yemenite victims is evident throughout the discourse of this Affair and constitutes the heart of the narratives related by the media. The system of representation, as Hall noted, always operates in connection to other systems in society. This connection is possible through what Said (1978) identifies as an "archive" of knowledge already produced and established through other narratives. This is evident in other historical examples and representations of Mizrahim in different media text (Shohat 1989, Avraham 1993, MadmoniGerber 2009).

Often, children of Yemenite mothers were described in the press as "dirty, disease- prone, and chronically malnourished..." (Stoler-Liss 2003, 108). In an article in Ha'aretz (September 12, 1997), Yael Dar demonstrated how narratives featuring stereotypical images of Yemenite children were already common in Hebrew literature from the 1940s and 1950s. Most depictions not only describe the Yemenite children as primitive, weak, and miserable, but also as coming from poor, un-nurturing and sometimes abusive families who forced their young children to go to work. Dar reviewed a variety of stories and demonstrated how they reflected the ideology of the Ashkenazi establishment at the time, pointing to the good fortune of the Yemenite children who happened to integrate with Ashkenazim.

Framing the Yemenite as "others" was possible through reinforcement of the negative racial stereotypes described above. Moreover, as Entman $(2007,164)$ argues, the process of framing is also intended to generate a particular "moral judgment, and promote a favored policy." 
European culture is considered to be superior and, as such, assimilation, or even integration via adoption was perceived as a way to "save" Oriental Jews, redeeming them from their primal "sin" of existing as part of the East (Shohat 1988). The narrative of rescue was especially prominent with the first TV exposure of this story on Channel One's investigative news magazine Mabat Sheni (September 24, 1986). ${ }^{18}$ At the time, Channel One was Israel's only television channel as well as the establishment's flagship voice. The program's production was of great concern to the Yemenite community, who feared that this broadcast would be instrumental in framing future discussions. Moreover, segments of this show were rebroadcasted in February of 1996, and the program in its entirety was aired yet again before this public channel was closed in March 2017. Despite mounting, and stunning new evidence, especially after the opening of the archive, the program proved somewhat more sympathetic to the plight of the parents, but ultimately referred back to the same old narrative that depicted the Affair as a result of some big misunderstanding and "balagan" (mess in Hebrew) during the immigration process; Yemeni babies who were adopted were rescued by good people, and were much better off with their new families.

The program followed the stories of three Yemenite girls who had been adopted. Editing was disjointed, so the testimony of a distraught Yemenite father looking for his daughter was confused with two Yemenite girls happily adopted by Ashkenazi families.

The show countered Yemenite accusations claiming that sick, misidentified children arrived daily to the absorption camps. Many who died, were neglected, or abandoned by their parents. Ashkenazi people adopted the remaining children to save their lives.

The show portrayed a distraught father named David Shuker ${ }^{19}$ who has been looking for his daughter since her disappearance in the 1950s. His search was extensive, well documented, and in the end, successful. Other stories were about two legally adopted girls who were living happily with their adoptive families. Tamar Tzuker, adopted by Ruth Tzuker of Haifa, was prominently featured. As a result, Shuker's tragedy was diminished. The implication was that Yemenite babies who were deserted by their parents fared better with adoptive families.

Tamar's adoptive mother Ruth was portrayed as a hero: "They suggested that I adopt a blond girl, but I said no; there is a long line of people who want the blond girl. If Tamar had no one, I wanted to adopt her." She added later that the doctor told her that due to neglect and illness,

Women in Judaism: A Multidisciplinary e-Journal Volume 17 Number 2 (2020) ISSN 1209-9392 (C) 2021 Women in Judaism, Inc.

All material in the journal is subject to copyright; copyright is held by the journal except where otherwise indicated. There is to be no reproduction or distribution of contents by any means without prior permission. Contents do not necessarily reflect the views of the editors. 
Tamar might be mentally challenged, but still she insisted on adopting her. (Mabat Sheni September 24, 1986). Ruth said that she located Tamar's parents, who did not object to the adoption; the ease in which parents were located in the Tzuker case versus the version of events presented by the nurses was never challenged. When asked if she wanted to find her biological parents, Tamar said, "No. Whoever deserted their child once cannot be looking for them now."

The program ended with Tamar's testimony. The placement implies that a genuine, happy adopted Yemenite child can speak authoritatively on the subject. She tells the camera she has no interest in her biological family and is much happier with her adoptive family. Hence, the "prying" Yemenite family was seen in a bad light — almost as criminals seeking to separate the girl from her home and the woman who saved her. Tamar's contentment served as rationale for the course of events and for the lack of public interest in investigation. For want of other opinions, viewers could conclude that other adult Yemenite adoptees felt the same way. Wherever Shuker's daughter was, the audience was led to believe that it was probably for the best.

The press response to this show was overwhelmingly supportive. The newspaper Davar's headline read "Just not another investigative commission" (September 30, 1986). Writers were full of praise for the "excellent investigation of the show" and cited the possible "emotional harm to the missing kids" as a reason to avoid investigation. Even the usually sharp and biting Heda Bushes called the show "excellent and fascinating," and "giving great expression to the human element" (Haaretz, September 26, 1986). Maariv (September 24, 1986) took a similar stand:

The show, just like the different commissions that dealt with this issue before, determined there were no kidnappings and no criminal acts...The show did good by airing the things that should be heard like the testimony of Tamar Tzuker-Kabiri..."

A few years later, Ha'aretz published an article recycling the story of Tamar Tzuker. The article focused on the misfortune of Tamar's early years and the kindness of her adoptive mother. Ruth's aristocratic and wealthy European roots were emphasized. She was characterized as a devoted and strong pioneer. In contrast, Tamar's life before adoption was portrayed as grim:

She was born somewhere in the south of Yemen, unwanted child to parents whose marriage was forced on them by old men in their community. She was brought to Israel on the eagle's wings 20 and was deserted in the immigrant's camp in Atlit, abandoned and dying. No one knew anything about her but that she had pneumonia and dysentery. If not for faith that brought them together, it is

Women in Judaism: A Multidisciplinary e-Journal Volume 17 Number 2 (2020) ISSN 1209-9392 (C) 2021 Women in Judaism, Inc.

All material in the journal is subject to copyright; copyright is held by the journal except where otherwise indicated. There is to be no reproduction or distribution of contents by any means without prior permission. Contents do not necessarily reflect the views of the editors. 
doubtful if Ruth would have found her happiness, if Tamar would have recovered and of course, this amazing story would never have been written (Ha'aretz November 3, 1989).

After a time, Ruth realized that she needed to complete the legal adoption process. A social worker helped her to locate Tamar's biological parents, who signed adoption papers. ${ }^{21}$ Tamar has never seen a picture of her parents, and she professes to have no interest in meeting them. As a child, Tamar was subjected to racism from people in her affluent Haifa neighborhood. ${ }^{22}$ She was called shvartze ("black" in Yiddish, used as a derogatory term) and individuals mistook her for the maid. Distanced from her ethnic background, Tamar did not seem bothered by these attitudes, in the interview, but she did object to being told about the adoption: "Why did you tell me that I was adopted?" she was quotes as telling her adoptive mother. "I wanted so much to be your child, the child you gave birth to...I would have never known that you are lying." (Ha'aretz November 3, 1989)

Tamar's story became an end unto itself. No longer the story of Yemenite families protesting the abduction of their children, it was transformed into a romantic tale of a young girl who was saved. The power of this narrative "to take over" the public sphere lies in its power to fit perfectly with the familiar notion that Mizrahim needed to be rescue. As Shohat (2004) argues, "the fantasy of rescue through modernity has led to the break-up of Mizrahi family" ${ }^{23}$ (p. 6).

From the early articles about the Yemenite Babies Affair of the 1960s, the media portrayed Yemenite Jews as "others." In addition to being seen as primitive and incapable of caring for themselves, some articles suggested they also have little to do with their children and sparse knowledge of childcare. ${ }^{24}$ Some parents were viewed as "having a tendency to forget about their children that were lost..." (Maariv September 2, 1966). Others described the Yemenite parents as seeing "for the first time in their lives how to bathe a baby and how to change a baby's diaper" (Davar February 24, 1967).

Absorption camp staff told the press and repeated later to the Kedmi Commission that Yemenite Jews were not terribly upset when they were told about the death of their children. "If a child died in the tent, they would say, 'God gives and God takes"' (Davar February 26, 1967). This view set the tone not only to dismiss the Yemenites claims since these parents didn't care if 
their children lived or died. Their religious beliefs in God as the determinant of human fate, and their tendency to internalize pain were interpreted by Ashkenazi doctors and nurses as a lack of care. ${ }^{25}$ The road to thinking they were unfit parents was very short, given this assumption. To use Entman's (2007) terms, theses preconceived notions "primed" audiences to have a specific attitude toward this affair. The process of "priming and framing," as Entman argues, "effect not just the definition of a problem, but moral judgment and remedy promotion (164)."

The ideological assumption that Zionism 'rescued' Mizrahim served to justify not only actions of adoption but also kidnapping, thus suggesting these children are treated better with their adoptive families. Ahuva Goldfarb, the head nurse of all absorption camp baby houses, went so far as to say, "Maybe we did them a favor" (Madmoni 1996). These racist sentiments were also echoed during nurses' testimonies to the commission and the press in the 1990s, leading to a narrative that directly blamed the parent.

When Sonia Milshtein, a head nurse at the camp baby houses, was asked if, as a mother, she could understand the families' pain, she replied, "Oh, I hear this too much lately. After forty years, I would have been happy that my child got a good education and a good family. Yes, that is how I would feel" (Yoman July 21, 1995). Milshtein repeated this remark to the Kedmi Commission's prosecutor, and when asked why she did not make it a priority to ensure that these babies were returned to their mothers, she replied, "I had other things to worry about" (Ha'ir October 27, 1995).

The Yemenites would also always be seen as lesser than European Caucasians, as demonstrated in nurse Milshtein's testimony to the Kedmi commission. She pointed her finger at the Yemenite mothers, claiming that she as a European mother would have searched more thoroughly to find her child (Yoman July 21, 1995). These boundaries were marked as Hall (1996, 445) argues in a way which "attempts to fix and naturalize the difference between belonging and otherness."

In another testimony given to the Kedmi Commission by Sara Perl, the chair of Wizo-Israel at the time, Yemenite families were again characterized as people who did not want their children. When Perl asked her manager why parents were not claiming their children, she said, "They just don't want their children, they have too much going on" (Ha 'ir November 3, 1995). 
Former prominent Ashkenazi journalist, Shelly Yehimovich said the Yemenite Babies conflict and its treatment by the media dehumanized the Yemenite community:

It is clear that the absorbing Ashkenazi institution did not relate to the Yemenite people like equals. It was as if they were taking babies from a primitive tribe; they thought that maybe they did them a favor. When you dehumanize an entire group of people, you do not identify with their pain (Interview, summer 2001).

The Yemenites were dehumanized beyond the categories of us/them; they were viewed as inhuman 'things.' Head nurse, Sonia Milshtein, mentioned earlier, shocked even the sleepy judge Cohen when she referred to Yemenite babies as "packages" and "carcasses" (Ha'ir October 27, 1995). The Kedmi Commission, however, did not reprimand her. Moreover, as opposed to hard questions directed at the Yemenite parents, Shubeli (2002) said that when the commission questioned nurses, doctors, and other government officials it was like "a casual conversation over a cup of coffee." In the end, as Sanjero $(2002,70)$ noted, only Yemenite parents were blamed in the commission's final report. He writes: "Throughout the report the commission detailed a dry description of severe actions without the slightest bit of criticism... in the entire report the commission did not name even one individual, flesh and blood, responsible...but blaming the parents they did..."

Parents were also blamed for their supposed silence since they did not speak up earlier, or worse they forgot about their children. Many say they were forced to defend themselves from false accusations as they relived their tragic losses.

In Tzipi Talmor's documentary Down-A One Way Road (1997) the following heartfelt testimony was given by Shlomo Bahagali, a Yemenite father who searched for his son Hayim for over 50 years:

I am talking to you, Hayim; this was not my fault. This is the fault of the people in charge. It isn't at all like they said that we were not interested in the babies. It is a cruel lie. That is why I am talking to you, Hayim; please in God's name, if you hear me, your ID number is 64703; please come back to me, let me rest in peace. I need to know that you are alive wherever you are.

\section{Lack of Closure}

The unresolved tragedy of the Yemenite Babies Affair will not fade with time, as some state leaders had hoped. The wounds of long-suffering mothers and fathers only deepen as the younger generations see the injustice wrought upon their families and community; they have made 
an unbreakable connection with the past and vow to fight for the recognition of their parents' narratives. Since 2014, a new wave of activism has emerged online, not only by younger people, but also by veteran activists who utilize social media to establish their protest. Some NGOs focus on researching the affair, documenting family narratives on video, and establishing protest and annual Awareness Days. Others focus on keeping pressure on the government via advocacy with Knesset members; they also use legal means such as petitions to the Supreme Court, and individual lawsuits. Through their online presence, all three organizations ${ }^{26}$ contribute greatly to what can be marked as an increased visibility of Mizrahim in the mainstream media, as well as a change in the public awareness about this affair.

Most notably, the renewed activism forced the government, in 2016, to disclose thousands of documents that were otherwise deemed confidential. And despite only partial disclosure, many documents already show incriminating lines of inquiry that were never taken by officials; ${ }^{27}$ this at the very least forces the government to admit that the archive documents raise more incriminating question rather than form any definitive answers. More recently, on February 2021, the Israeli government passed a resolution that would "recognize families' pain," and offer some financial compensation, but conspicuously the document lacked an official recognition or any public expression of States' responsibility. The phrasing of this decision did not even indicate that babies and young children were forcefully removed from their parents due to a clear state policy; a fact that is not disputed even by the last commissions' conclusions. As recently as March 30, 2021, the news site Walla exposed an initial report by the Ministry of Health documenting how Yemeni parents were intentionally mislead by officials to sign documents that would allow them to take their kids for adoption. Based on dozens of testimonies by physicians and nurses, the report points to a "racist and systematic method that was widespread. ${ }^{28 "}$ Moreover, as Ruth Amir (2019) argues, even with the absence of a written law requiring the separation of children from their families, the state of Israel is still responsible. The forcible transfer of babies to the "baby house" structures in the transit camps was done by the authorities who neglected their responsibility to keep track of them; following other legal precedents given by the international court, Amir $(2019,150)$ argues that "these actions are a testament to the state's intention..." 
The absence of such acknowledgement drew wide criticism from activists and families who highlighted the ongoing legal procedures as what motivated the government's decision. In an article published in Ha'aretz (February 28, 2021), journalist and activist Yael Tzadok called the decision manipulative and another attempt to silence families. "This isn't motivated by a real desire to offer justice for the families...but stems from a fear of more legal challenges," she wrote. Another family member, Michael Sharabi, told the Times of Israel (February 23, 2021) that monetary compensation is not a substitute for the truth. "We want them to open all the cases and hidden files, recognize the responsibility of the state, and apologize to the families for all the injustice," he said.

The renewed activism, especially the enthusiastic involvement of the younger generation, demonstrates that cultural identity is intimately linked to history, and "belongs to the future as much as to the past" (Hall 1990, 394). Social media connected activists to global anti-racist language and campaigns intended to dismantle long standing power structures. The moment of reckoning experienced in North America and the strong public presence of the BLM and \#MeToo movements finally gave victims' testimonies the attention and center stage they deserve. Similarly, the state of Israel and the public must fully listen and truly regard parents' narratives; they have a right to be heard.

To date hundreds of testimonies have been filed to all three state commissions combined, detailing the forceful separation of babies and children from their parents. By any measure, a level of irrefutable witness. Considering even the most conservative of estimates, over 1,000 mothers and fathers stood in public and said: "My child was taking away from me too..." "They told me she died, but I never saw a body or a grave... MeToo." Many second and third generation Yemenis, as well as other Mizrahim (myself included), grew up in families haunted by these narratives. By documenting and highlighting testimonies, activists have focused on the power embodied in the common thread that connects these stories. In addition, despite the many issues with social media, the power of its activism lies in the ability to wedge an opening in the dominance of mainstream gatekeepers. The biggest achievement of the \#MeToo movement is the cumulative power of its many components. By reframing the story and forcing the public to listen, activists wrested control of the narrative and brought it back to its rightful owners; the need for a wider social responsibility 
became painfully clear. This is exactly how we should consider the narratives of the kidnapping of hundreds (if not thousands) of Mizrahi babies. It is neither an isolated story nor a "Yemenite problem." We are all implicated in this story whether we like it or not.

Only a little over a year ago, on January 2020, the Israeli Supreme Court finally joined the right side of history by rejecting the state's efforts to isolate the narratives of 11 families that are currently suing the state; the most substantial legal achievement thus far. More than seven decades too late, the law has finally sought to spotlight the perspective of the families. Among them are five parents, now in their 90s, giving us a last-minute chance to listen and act. It is our moral obligation - as a state and as individuals - to do just that.

\section{Selected Bibliography:}

Avraham, E. (1993) The Media in Israel: Center and Periphery. Tel Aviv: Breirot Publishers (Hebrew).

Amir, R. (2019) The Yemenite Children Affair in Light of the Phenomenon of Forceful Transfer of Children in the $20^{\text {th }}$ Century. In: Gamliel $\mathrm{T}$ and Shifris N (eds) Children of the Heart: New Aspects of Research in the Yemenite Children Affair. Tel Aviv: Resling, pp. 117-162 (Hebrew)

Ben Dor, Z. "Klipa Megeza Hatut: Haikar, Hapoel, Vehasatan Hateimani Shelahem. Haoketz first published in Kedma November 7, 2009.

Druyan, N. (1981) Without A Magic Carpet. Jerusalem: Ben Tzva Institute (Hebrew).

Entman, Robert. (2007) Framing Bias: Media in the Distribution of Power. Journal of Communication 57(1): 163-173.

Foucault, Michel. (1972). The Archaeology of Knowledge \& the Discourse of Language. New York: Pantheon Books.

Foucault, Michel. (1980). Power/Knowledge, New York: Pantheon Books.

Women in Judaism: A Multidisciplinary e-Journal Volume 17 Number 2 (2020) ISSN 1209-9392 (C) 2021 Women in Judaism, Inc.

All material in the journal is subject to copyright; copyright is held by the journal except where otherwise indicated. There is to be no reproduction or distribution of contents by any means without prior permission. Contents do not necessarily reflect the views of the editors. 
Chetrit, Shalom Chetrit. (1999) The Ashkenazi Revolution is Dead: Thoughts about Israel from a Dark Angle. Tel Aviv: Bimat Kedem Lesifrut (Hebrew).

Hall, Stuart. (1990) Cultural Identity and Diaspora. Identity: Community, Culture, Difference' (Ed.) Jonathan Rutherford. London: Lawrence \& Wishart, 1990, pp. 222-237.

Hall, Stuart. (1992) The West and the Rest: Discourse and Power. In S Hall and B Gieben (eds) Formations of Modernity Cambridge: Polity Press, pp. 275-331.

Hall, Stuart. (1996) Cultural Identity and Cinematic Representation. In Morley D and Kuan-Hsing C (eds) Stuart Hall: Critical Dialogues In Cultural Studies. London and New York: Routledge, pp. 441-449.

Haziza, Natalie. (2019) Traces of Absence: How the trauma of the Yemenite, Mizrahi and Balkan Kidnapped Children Affair is presented in home-movies and photographs. Mizrahi Legal Studies Conference, Harvard University, December 2019. Cambridge: MA.

Hertzog Esther. (1999) Immigrants and Bureaucrats: Ethiopians in an Israeli Absorption Center. Oxford: Berghahn Books.

Hertzog, Esther. (2019) Expropriation of Parenthood: From the Yemenite Children Until Today. In: Gamliel T and Shifris N (eds) Children of the Heart: New Aspects of Research in the Yemenite Children Affair. Tel Aviv: Resling, pp. 163-203. (Hebrew)

Hirsch Dafna. (2009) "We are Here to Bring the West Not Only to Ourselves:" Zionist Occidentalism and the Discourse of Hygiene in Mandate Palestine. International Journal of Middle East Studies 41(4): 577-594.

Kedmi, Yakov. (2001) Investigative Public Commission in the Matter of the Disappearance of Yemenite Children During 1948-154. A report, for the department of Justice, Jerusalem.

Lavie, Smadar. (2007) Dry Twigs. http://electronicintifada.net/v2/article7132.shtml

Lavie, Smadar, (2014) Wrapped in The Flag of Israel: Mizrahi Single Mothers and Bureaucratic Torture. Oxford: Berghahn Books.

Madmoni, Shoshana. (1996) The Women in Front. Noga (30): 20-23 (Hebrew).

Madmoni-Gerber, Shoshana. (2003). Orientalism Reconsidered: Israeli Media and the Articulation of Resistance. Cultural Studies 17:2.

Madmoni-Gerber, Shoshana. (2009). Israeli Media and the Framing of Internal Conflict: Yemenite Babies Affair. New York: Palgrave Macmillan 
Madmoni-Gerber, Shoshana. (2019) Coverage or Cover-Up? The Yemenite Children Affair as Reflected in the Media. In: Gamliel T and Shifris N (eds) Children of the Heart: New Aspects of Research in the Yemenite Children Affair. Tel Aviv: Resling, pp. 531-576. (Hebrew)

Meir, Yosef. (1983). The Zionism Movement and the Yemenite Jews. Tel-Aviv: Afikim Library Publishers (Hebrew).

Nini, Yehuda. (1996) Kineret's Yemenites: Their Settlment and Removal from the Land: 19121930. Tel Aviv: Am Oved Publishers (Hebrew).

Said, Edward. (1978) Orientalism. New York: Random House.

Sanjero, Boaz. (2002) "When There Is No Suspicion There Is No Real Investigation."

Teoriya Vebikoret 21: 47-76 (Hebrew).

Shifris, Natan. (2019) Where Have All the Children Gone: The Kidnapped Yemenite Babies Affair and Its Denial. Tel Aviv: Yediot Books

Shohat, Ella. (1988) Sepharadim in Israel: Zionism from the Stand Point of its Jewish Victims. Social Text: Theory, Culture and Ideology 19/20: 1-35.

Shohat, Ella. (2003) "Rupture and Return: Zionist Discourse and the Study of Arab-Jews," Social Text 21, no. 2 (2003). Duke University Press.

Shohat, Ella. (2004). "The Postcolonial in Translation: Reading Said in Hebrew." Journal of Palestine Studies 33 (2004).

Shubeli, Rafi. (2013) The Yemenite Babies Affair: Historical Background. Afikim (April): 127133 (Hebrew).

Soffer, Oren. (1998) Center and Periphery in the Journalistic Discourse: Analysis from the Dialoguecal Philosophy Perspective. Master Thesis: Tel Aviv University.

Stoler-Liss, Sachlav. (2003) "Mothers Birth the Nation": The Social Construction of Zionist Motherhood in Wartime. Nashim: A Journal of Jewish Women's Studies \& Gender (6): 104-118

West, Cornel. (1993) Race Matters. Boston: Beacon Press.

Zaid, Shoshi. (2016) The Child is Still Gone. Israel: Media 10 (Hebrew)

Zinn, Howard. (2007) A Power Governments Cannot Suppress. San Francisco: City Lights Books

Women in Judaism: A Multidisciplinary e-Journal Volume 17 Number 2 (2020) ISSN 1209-9392 (C) 2021 Women in Judaism, Inc.

All material in the journal is subject to copyright; copyright is held by the journal except where otherwise indicated. There is to be no reproduction or distribution of contents by any means without prior permission. Contents do not necessarily reflect the views of the editors. 


\section{Whitewashing Narratives: Israeli Media and the Framing of the Kidnapped Yemenite Babies Affair}

\section{Endnotes:}

${ }^{1}$ The nurse was audio taped by Avner Farhi, whose sister was kidnapped from Ein-Shemer Camp in 1950.

${ }^{2}$ Shuker's story was also featured on $U v d a$ (February 1996) and on the newspaper Shishi. I wrote this story as a journalist for Shishi at the time. I also conducted the research for the show Uvda.

${ }^{3}$ For the print media discourse, I had access to the inclusive archives of the newspapers Maariv and Yediot Aharonot, which included newspaper clippings from all daily newspapers (and magazines) that published stories on this Affair. This includes Haaretz Davar Al Hamishmar Ha'olam Haze Laisha and some local newspapers. I also analyzed the show Mabat Sheni on channel 1, aired in 1986, and the shows Bamat Sheni, Uvda and Hasifa aired on February 1996. This article includes only few examples. The complete analysis is detailed in my book Israeli Media and the Framing of Internal Conflict (2009).

${ }^{4}$ I conducted most of my interviews during June-July 2001. I spoke with most interviewees again during May-June of 2008. Some interviews were conducted for the first time during the summer of 2008. All my interviewees agreed to be quoted in their full name.

${ }^{5}$ For a more detailed analysis of Rabbi Meshulam protest see "Orientalism Reconsidered," in Cultural Studies (2003) and Israeli Media and the Framing of Internal Conflict The Yemenite babies Affair (2009), chapter 5.

${ }^{6}$ All the data is from the Kedmi Commission report (Jerusalem 2001: 21-27)

${ }^{7}$ The above quotes are from Hayim Malka's book The Selection (1998, 51-52).

${ }^{8}$ On February 22, 1985, Ha'ir published the first article presenting another point of view about the Yemenite Babies Affair, accompanied by hard evidence and pointing to the state's deliberate avoidance of a proper investigation. The article, written by Ilan Maget, told of patronizing, well-intentioned investigators with no power who were replaced by a superficial government investigation.

${ }^{9}$ Many of my interviewees, prominent journalists and activists claimed that the government's primary motive in silencing and minimizing the Yemenite Babies Affair was to preserve Zionist ideology and Ashkenazi hegemony. Each felt that the media, knowingly or not, was dominated by Zionist ideology, which was grounded in the notion that the Jewish people's strength lay in their ability to work together. Accordingly, most journalists felt that maintaining unity was a shared responsibility, which led to self-censorship. They operated in what Gramsci's termed "hegemony by consent," not by coercion.

${ }^{10}$ The articles in Ha'air and Haaretz were published in 1995-1996. The programs Uvda and Hasifa aired on Channel Two in February 1996.

${ }^{11}$ Coverage of the Yemenite Community's activities, and demands was sporadic at best. Shohat noted, for example, that after a major demonstration (in 1986), demanding investigation of the kidnapping, the Israeli media ignored the protest, but the Israeli TV (owned by the government) produced a documentary that blamed the parents for the disappearance of the children, producing an Orientalist narrative (Shohat 1988, 17-18).

${ }^{12}$ Some writers such as Dan Margalit in Maariv were more skeptical questioning, for instance, the response of the Jewish Agency on this matter (September 4, 1966).

${ }^{13}$ More on the text of this show later in the article.

${ }^{14}$ Shohat (1990) "Master Narrative/Counter Readings" in Resisting Images: Essays on Cinema and History, Robert Sklar \& Charles Musser (eds.).Temple University Press.

${ }^{15}$ Even the superficial work of the Kedmi Commission indicated that separation of children from their parents was intentional. Improper identification and paperwork were primary contributors to the separation of parents from their babies.

${ }^{16}$ See more on this report in the last section of this essay.

${ }^{17}$ Sociologist and education activists Shlomo Swirski reported a similar experience. When he requested help from the human rights organization for violation of laws in education to Mizrahim in the periphery, he said, their response and unwillingness to help was chilling (Interview, summer 2001).

${ }^{18}$ This program was one of the most viewed programs on TV at the time. As other shows aired on Channel One, it lacked a fresh critical outlook and tended to reflect more conservative institutional opinions.

${ }^{19}$ I interviewed Shuker twice and I am familiar with the details of his story.

Women in Judaism: A Multidisciplinary e-Journal Volume 17 Number 2 (2020) ISSN 1209-9392 (C) 2021 Women in Judaism, Inc.

All material in the journal is subject to copyright; copyright is held by the journal except where otherwise indicated. There is to be no reproduction or distribution of contents by any means without prior permission. Contents do not necessarily reflect the views of the editors. 
${ }^{20}$ Both "Eagle's Wings" and "Magic Carpet" were the names that were used to describe the Yemenite immigration from 1949 to 1951. Eagles Wing was taken from a verse in the Bible "Vee'le Etchem Al Kanfey Nesharim" and was used by Yemenites to describe the messianic feeling they had about what they thought was going to be the beginning of redemption (geula). The name Magic Carpet, on the other hand, was given to this immigration by the Zionist institutions and it is aligned with the other Orientalist stereotypical views of this immigration.

${ }^{21}$ It is interesting to note the ease with which Tamar's parents were located when the adoptive parents wanted to complete the adoption, but no one knew where to find them when the girl was abandoned in the camp. The case of Miriam Shuker presents a similar problem. While the state determined that the baby had been legally adopted although the parents had never signed adoption papers and continued to look for their children.

${ }^{22}$ Tamar grew up in Hacarmel, an affluent neighborhood of Haifa, where the majority of people were of German descent. The term shvartze ("black" in German/Yiddish) was a negative term used by Ashkenazim to denote Mizrahim.

${ }^{23}$ For Shohat, the kidnapping formed part of the broader Eurocentrism of the Zionist Enlightenment discourse of progress and modernization, viewing itself as rescuing Middle Eastern Jews (Shohat 1988). See also her analysis in "The Narrative of the Nation and the Discourse of Modernization: the Case of the Mizrahim" Critique 10 (Spring 1997).

${ }^{24}$ Among other things, the fact that Yemenite mothers nursed their babies for two or three years was seen as a sign of ignorance and primitive behavior that resulted in poor nutrition. Needless to say, nursing for at least a year is considered by pediatricians, to be the best thing a mother can do for her baby.

${ }^{25}$ As Talal Asad $(1993,200)$ noted, the West tended to evaluate non-Western traditions "according to their distance from enlightenment and liberal models."

${ }^{26}$ The organizations are called in Hebrew: Amram, Ahim Vekayamim and Forum Ehai.

${ }^{27}$ Two articles published in Haaretz on January $20^{\text {th }}$, and February $16^{\text {th }} 2017$, revealed documents pointing to a system of what was termed by investigators "a mysterious late registration" of babies; this made it possible to transfer kids to adoptive families without an official adoption process. The investigators point to over 300 such registration centers in different localities across the country. In some cases, they were able to register babies even a year after birth. "This means that 'parents' who showed up before the 'late registration' clerk could have left that office with a 'birth certificate' showing that they were the biological parents of this child." (Haaretz, 2/16/2017). This kind of finding, of course, points to the complexity of the investigation; if documents and registrations were forged in this way, how can we rely on them to provide definitive answers?

${ }^{28}$ The article also noted, that while the official document was complete a year earlier by the Ministry of Health, it wasn't officially published yet. For more details see:

https://news.walla.co.il/item/3426105?utm campaign=socialbutton\&utm content=whatsapp\&utm medium=shareb utton\&utm source=whatsapp\&utm term=social

Women in Judaism: A Multidisciplinary e-Journal Volume 17 Number 2 (2020) ISSN 1209-9392 (C) 2021 Women in Judaism, Inc.

All material in the journal is subject to copyright; copyright is held by the journal except where otherwise indicated. There is to be no reproduction or distribution of contents by any means without prior permission. Contents do not necessarily reflect the views of the editors. 